\title{
Photovoltaic Application Study of Zinc Telluride Thin Films Grown by Chemical Bath Deposition Method
}

\author{
Kisan C. Rathod ${ }^{1}$, Pradip D. Kamble², Kallappa R. Sanadi ${ }^{3}$, Ganesh S. Kamble4, \\ Muddsar L. Guar5, Kalyanrao M. Garadkar6
}

${ }^{1}$ Department of Chemistry, The New College, Kolhapur, MH, India

${ }^{2}$ Department of Physics, The New College, Kolhapur, MH, India

${ }^{3}$ Department of Chemistry, Doodhsakhar Mahavidyalaya, Bidri, Kolhapur, MH, India

${ }^{4}$ Department of Engineering Chemistry, Kolhapur Institute of Technology's College of Engineering, Kolhapur, MH, India

${ }^{5}$ Department of Chemistry, C.B. Khedgi's Basaveshwar Science Raja Vijaysinh Commerce and Raja Jaysinh Arts College, Akkalkot Solapur, MH, India

${ }^{6}$ Department of Chemistry, Shivaji University, Kolhapur, MH, India

Email: *kishanchandurathod@gmail.com

How to cite this paper: Rathod, K.C., Kamble, P.D., Sanadi, K.R., Kamble, G.S., Guar, M.L. and Garadkar, K.M. (2021) Photovoltaic Application Study of Zinc Telluride Thin Films Grown by Chemical Bath Deposition Method. Advances in Materials Physics and Chemistry, 11, 131-144. https://doi.org/10.4236/ampc.2021.118013

Received: May 6, 2021

Accepted: August 24, 2021

Published: August 27, 2021

Copyright $\odot 2021$ by author(s) and Scientific Research Publishing Inc. This work is licensed under the Creative Commons Attribution International License (CC BY 4.0).

http://creativecommons.org/licenses/by/4.0/

\begin{abstract}
Photovoltaic solar thin films zinc telluride studies on chemically deposited have been carried out to assess its suitability for use in the conversion of solar energy to electrical energy. The configuration of fabricated cell is $n-Z n T e \mid ~ N a O H$ $(0.1 \mathrm{M})+\mathrm{S}(0.1 \mathrm{M})+\mathrm{Na}_{2} \mathrm{~S}(0.1 \mathrm{M}) \mid \mathrm{C}_{\text {(graphite) }}$. The study shows that $\mathrm{ZnTe}$ thin films are n-type conductivity. The junction ideality factor was found to be 2.87. The flat band potential is found to be $-0.652 \mathrm{~V}$. The barrier height value was found to be $0.583 \mathrm{eV}$. The study of the power output characteristic shows open circuit voltage, short circuit current, fill factor and efficiency were found to be $150 \mathrm{mV}, 25.6 \mu \mathrm{A}, 24.86 \%$ and $0.49 \%$, respectively. The photovoltaic cell characterization of the thin films is carried out by studying current-voltage characteristics in dark, capacitance-voltage in dark, barrier height measurements, power output characteristics.
\end{abstract}

\section{Keywords}

CBD, Thin Film, Photovoltaic Cell, $I-V, C$ - $V$ in Dark, Barrier Height

\section{Introduction}

One of the most power full alternatives energy sources for future large-scale electricity production is photovoltaics that is the conversion of sunlight directly 
into electricity. The use of photovoltaic cells (PVC) utilizing thin films semiconductor materials, as a direct route to harness solar energy has become a subject of intensive research due to its overriding advantages over the other conventional devices. The photovoltaic cells are much cheaper, simple to construct and need no complicated processing steps. As the PVC utilizing a polycrystalline aggregate can achieve $67 \%$ efficiency of the same material in a single crystal form [1]. The efficiency and stability of PVC depend strongly on the preparation condition of the photoelectrodes, electrolytes and the experimental conditions set during the experimentation [2]. Unlike semiconductor-semiconductor junction in solar cells, the semiconductor-electrolyte junction in PVC is readily established so that the study of junction energetics becomes easy [3] [4] [5]. The binary semiconductor materials are known to function effectively in conversion of solar energy into electrical energy [6] [7].

Zinc telluride is a wide band gap material at room temperature. It is efficiently used in gray, and light gray light-emitting diodes, photovoltaics, laser screens, thin films transistor and photovoltaic cells [8] [9] [10]. In photovoltaic cells (PVC), the use is made of the interface which forms on mere dipping the semiconductor into an electrolyte solution and the liquid junction potential barrier can be easily established [11] [12]. Thus, PVC cells provide an economic chemical route for trapping solar energy [13]. Along with PVC, the semiconductor electrolyte interface may be used for photoelectrolysis, photocatalysis and photovoltaic power generation [14].

The properties of such systems are mainly dependent on the interface formed between the semiconductor electrode and electrolyte hence from material point of view the microstructure of the photoelectrode surface is of main importance [15]. We reported the successful deposition of crystalline zinc telluride thin films by the chemical bath deposition technique. Growth mechanism, structural, morphological, optical, electrical and thermoelectrically properties are studied [16]. This paper revels the study of photovoltaic performance of chemically deposited Zinc telluride photo electrode which include I-V, C-V characteristics, barrier height measurements, power out curves, spectral response and photo response. Series and shunt resistance in solar cells are parasitic parameters, which affect the illumination current-voltage $(I-V)$ characteristics and efficiency of cells. Very high values of series resistance $\left(R_{s}\right)$ and very low values of shunt resistance $\left(R_{s h}\right)$ reduce short-circuit current $\left(I_{s c}\right)$ and open-circuit voltage ( $\left.V_{o c}\right)$ respectively. In this study, the analysis of $\left(R_{s}\right)$ and $\left(R_{s h}\right)$ is for the zinc telluride solar cells.

\section{Experimental Details}

\subsection{Construction and Working of Photovoltaic Cell}

The Photovoltaic cell is the semiconductor device that converts light into electrical energy. The electrons of the semiconductor material are joined together by the covalent bond. The electromagnetic radiations are made of small energy particles called photons. When the photons are incident on the semiconductor material, then the electrons become energised and starts emitting solar energy is 
shown in Figure 1. A simple photovoltaic solar cell is formed a p-n junction diode. The schematic of the p-n junction device is shown in Figure 2. The n-type region is heavily doped and thin so that the light can penetrate through it easily. The p-type region is lighted doped so that most of the depletion region lies in the p-type region side. The penetration depends on the deposition thickness of the thin films. Electron hole pairs are mainly created in the depletion region and due to the built-in potential and electric field because electrons move to the n-type region and the holes move to the p-type region. When the external load is applied, the excess electrons travel through the load to recombine with the excess holes. The electrons and holes are also generated with the p-type and n-type regions. The thinner thin films absorb the higher light in the n-type

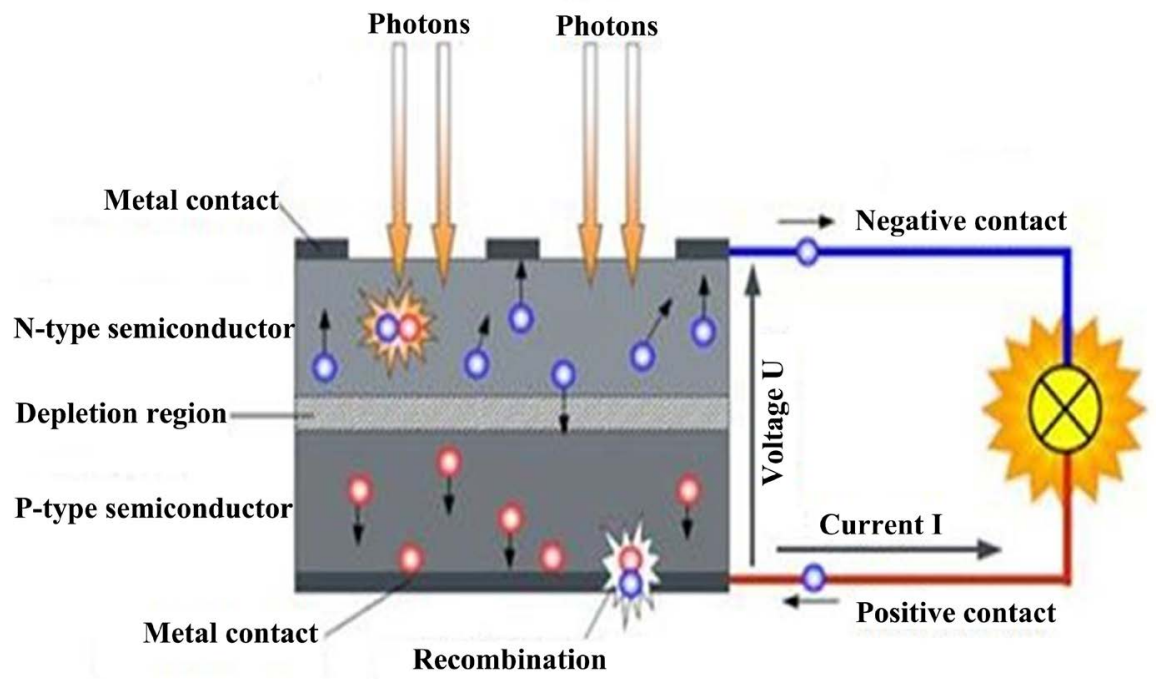

Hole $=$ positive charge

O Electron $=$ negative charge

Figure 1. Construction and working of PV solar cell.

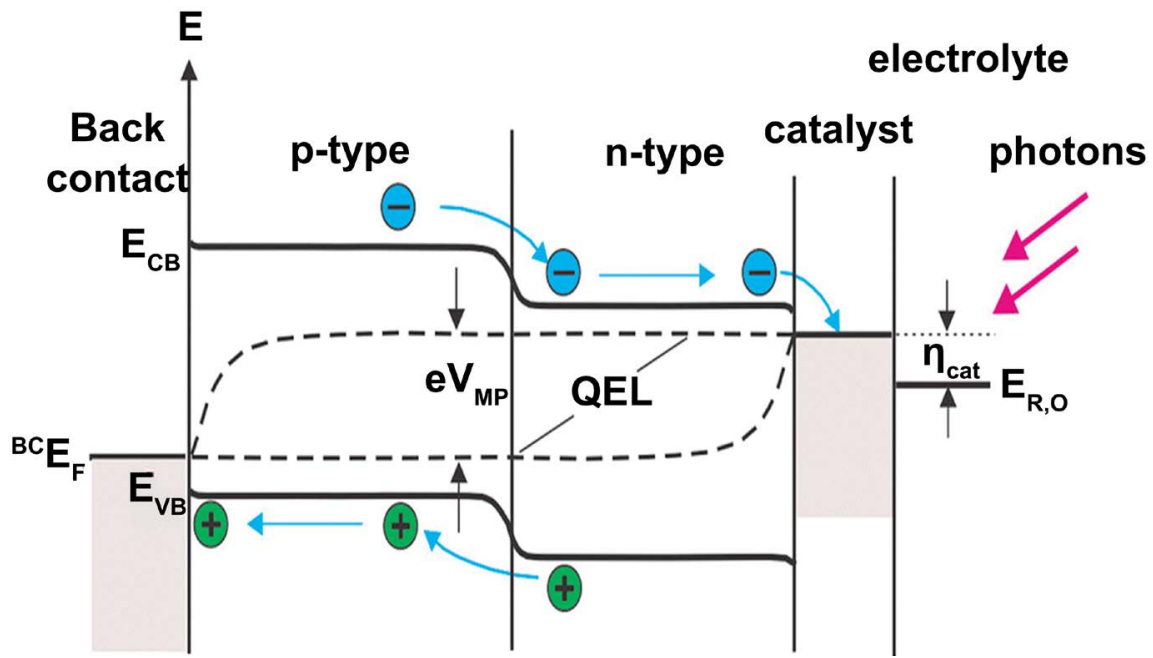

Figure 2. Formation of the p-n junction diode in PV solar cell. 
region and thicker thin films absorb the lower light in the p-type region. Electron hole pairs are generated in these regions can also contribute to the current. Generally, these electron-hole pairs are generated within the minority current carrier diffusion length of thin films for electrons in the p-type region and holes in the $\mathrm{n}$-type region.

\subsection{Synthesis of ZnTe Thin Films}

The chemicals used for the preparation of zinc telluride thin films were used as the chemical is AR grade zinc sulphate, tartaric acid, liquor ammonia, sodium sulphite and selenium. Sodium telenosulphate was prepared by the following method reported earlier [17]. In actual experimentation, $10 \mathrm{~mL}(0.2 \mathrm{M})$ zinc sulphate was taken in $250 \mathrm{~mL}$ beaker. $2.5 \mathrm{~mL}(1 \mathrm{M})$ tartaric acid, $10 \mathrm{~mL}(1 \%)$ liquor ammonia and $10 \mathrm{~mL}(0.25 \mathrm{M})$ sodium telenosulphate were added in the reaction bath. The total volume of the reactive mixture was made up to $100 \mathrm{~mL}$ by adding double distilled water. The beaker containing the reactive solution was transferred to an oil bath at $278 \mathrm{~K}$ temperature. The $\mathrm{pH}$ of the resulting solution was found to be $10.05 \pm 0.05$. To obtain the film, four stainless steel plate substrates were positioned vertically on a specially designed substrate holder and rotated in a reactive solution with a speed of $52 \pm 2 \mathrm{rpm}$. The temperature of the solution was then allowed to rise slowly to $359 \pm 5 \mathrm{~K}$. The substrates were subsequently removed from the beaker after $6 \mathrm{~h}$ of deposition. Figure 3 is shown by the experimental deposition of the solar thin film.

\subsection{Fabrication of PVC Cell}

A calomel electrode is used as a reference electrode and sulphide-polysulphide as an electrolyte is shown in Figure 4. Photovoltaic cell is consisting of threeelectrode configurations are used in experiment. Zinc telluride as photoanode, CoStreated graphite rod as a counter electrode. This electrode acts as a photocathode.

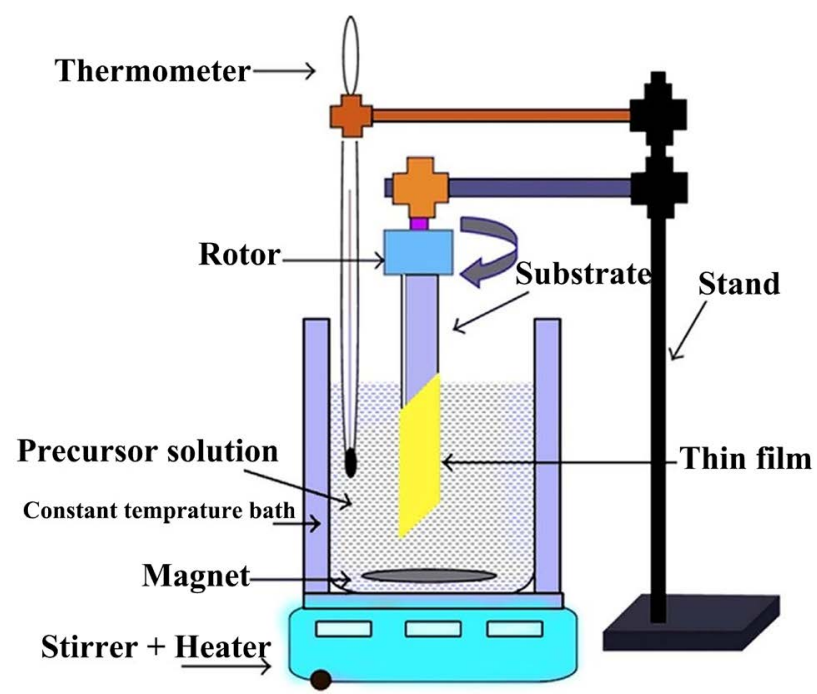

Figure 3. Experimental setup of CBD method to deposition of thin film. 


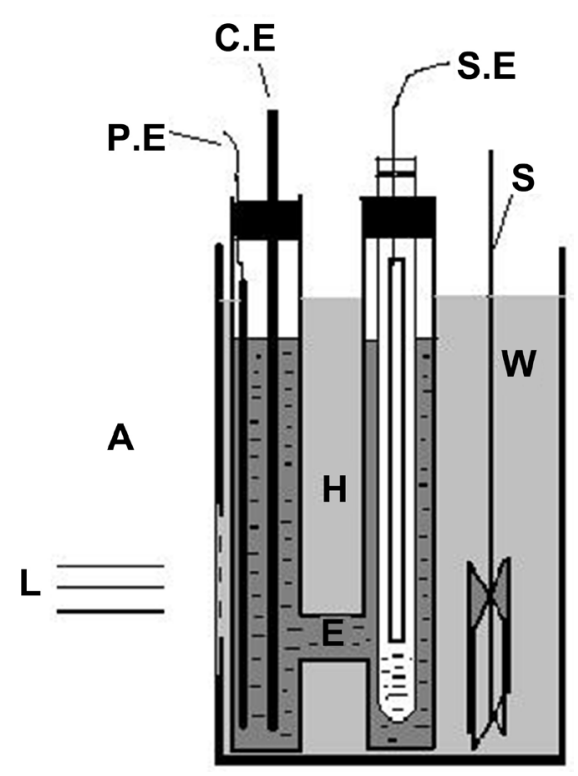

Figure 4. A schematic diagram of photovoltaic solar cell electrode. L: Light; A: Anode; P.E.: Photoelectrode; C.E.: Counter Electrode; S.E.: Standard Calomel Electrode; S: Stirrer; W: Water; H: "H" shaped cell, E: Electrolyte.

\subsection{Characterization of PVC Cell}

The Mott-Schottky plot is used to determine the flat band potential One-kilohertz frequency is used to determine the flat band potential. The illuminated area of electrode was $3.0 \mathrm{~cm}^{2}$. The type of conductivity exhibited by the film is determined by nothing the polarity of the emf developed in PVC cell under illumination. The current-voltage ( $I-V)$ characteristic in dark has been plotted. The junction ideality factor has been determined by plotting the graph of $\log I$ versus $V$. The fill factor and power conversion efficiency of the cell is calculated from photovoltaic power output characteristics. The fill factor and power conversion efficiency of the cell are calculated from photovoltaic power output characteristics. The power output characteristic has been obtained for a PEC cell at a constant illumination of $30 \mathrm{~mW} / \mathrm{cm}^{2}$.

\section{Results and Discussion}

\subsection{Conductivity Type}

A photovoltaic cell with configuration $n-Z n T e \mid N a O H(0.1 M)+\mathrm{S}(0.1 \mathrm{M})+\mathrm{Na}_{2} \mathrm{~S}$ $(0.1 \mathrm{M}) \mid \mathrm{C}_{\text {(graphite) }}$ was formed. PVC cell shows dark voltage and dark current even in the dark. The polarity of this dark voltage was negative towards semiconductor electrode. The sign of the photovoltage gives the conductivity type of ZnTe. This suggests that $\mathrm{ZnTe}$ is an $\mathrm{n}$-type conductor which has also been proved from TEP measurement studies [18].

\subsection{I-V, $C-V$ Characteristics in Dark}

Photovoltaic cell of zinc telluride thin films current-voltage $(I-V)$ characteristics in dark have been studied at $300 \mathrm{~K}$ and shown in Figure 5. The characteristics 


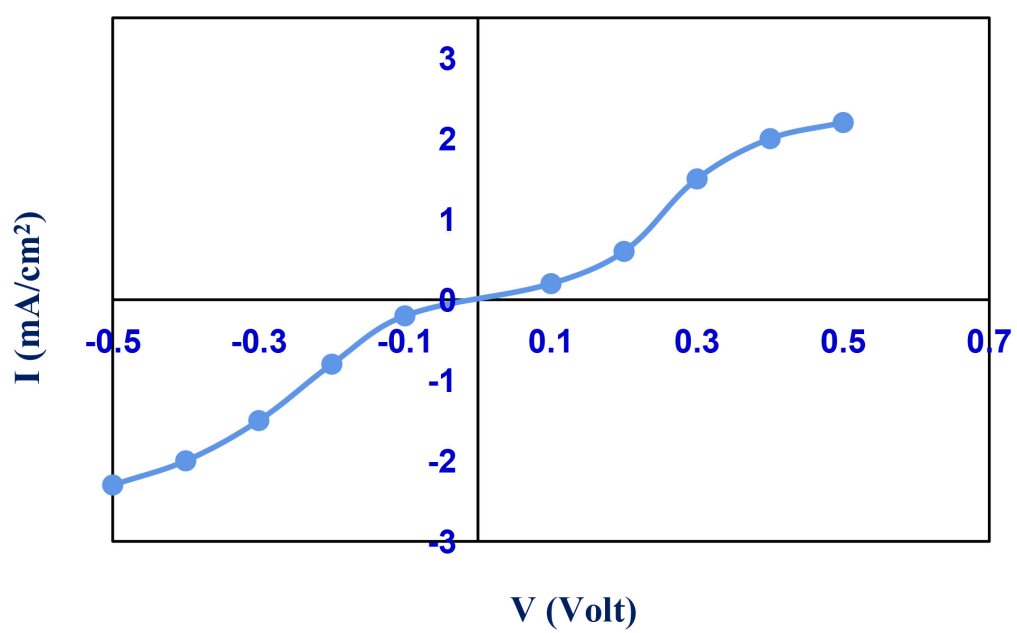

Figure 5. I-V characteristics of $\mathrm{ZnTe}$ photovoltaic solar cell (in dark).

are symmetrical indicating the formation of rectifying type junction [19]. Using famous ideal Schottky diode equation junction ideality factor is calculated from the equation [20] [21].

$$
I=\left[\frac{I_{0} e^{e v}}{n_{d} k T}\right] .
$$

where, $I$, is the forward current in dark, $I_{0}$, reverse saturation current, $V$, applied forward bias voltage and $n_{d}$ is the junction ideality factor. The value of junction ideality factor $\left(n_{d}\right)$ can be determined of the linear regions of the $\log (I)$ versus volt $(V)$ are shown in Figure 6. The ideality factor was found to be 2.27 . The higher value of $n_{d}$ suggests the dominance of series resistance as well as structural imperfection. It also suggests that average transfer across the semiconductor electrolyte interface with significant contribution from surface states and deep traps [22].

The PVC cells of capacitance are measurements as a function of applied voltage provided useful information such as type of conductivity, depletion layer width and flat band potential $\left(V_{f b}\right)$. The flat band potential of a semiconductor gives information of the relative position of the fermi levels in photoelectrode as well as the influence of electrolyte and charge transfer process across the junction. This is also useful to measure the maximum open circuit voltage $\left(V_{o c}\right)$ that can be obtained from a cell. Measured capacitance is the sum of the capacitance due to depletion layers and Helmholtz layer in electrolyte which is neglected by assuming high ionic concentration [5]. Under such circumstances, $V_{f b}$ can be obtained using Mott-Schottky relation by standardizing with saturated calomel electrode (SCE).

$$
C^{-2}=\left[\frac{2}{q \varepsilon_{s} \varepsilon_{0} N_{d}}\right] \times\left[\frac{V-V_{f b}-k T}{q}\right] .
$$

where the terms involved have meaning, $C^{-2}$ is space charge capacitance per unit area, $q$ the electronic charge, $\varepsilon_{s}$ is the dielectric constant of the semiconductor 


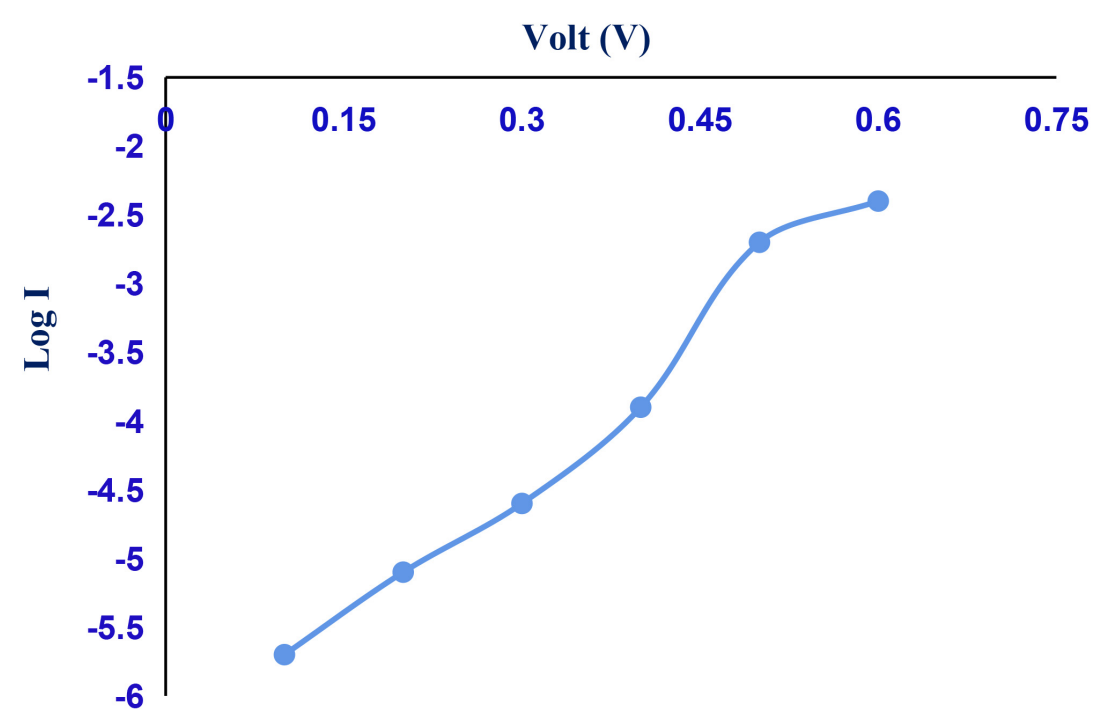

Figure 6. Determination of junction ideality factor of ZnTe photovoltaic solar cell.

electrode, $\varepsilon_{0}$ is the permittivity of the free space, $N_{d}$ the donor density, $k$ the Boltzmann constant, $T$ the absolute temperature, $V$ the applied potential and $V_{f b}$ is the flat band potential. The $1 / C^{-2}$ versus voltage $(\mathrm{mV})$ plots (Mott-Schottky plot) were constructed for the sample and are shown in Figure 7. Intercepts of plots on voltage axis determine the flat band potential value of the junction. The flat band potential value was found to be -0.652 (SCE) for ZnTe-polysulphide redox electrolyte, which is a measure of electrode potential at which band bending is zero. The non-linear nature of the graph is an indication of graded junction formation between $\mathrm{ZnTe}$ and polysulphide electrolyte may be possible reasons for deviation from linearity in $C$ - $V$ plot.

\subsection{Barrier Height Measurements}

The photovoltaic solar cell zinc telluride thin films barrier height was determined by measuring the reverse saturation current $\left(I_{0}\right)$ through the junction at different temperature from 370 to $315 \mathrm{~K}$. The reverse saturation current flowing through junction is related to temperature as [21].

$$
I_{0}=A T^{2} \exp \left[\frac{\varphi_{\beta}}{k T}\right]
$$

where, $A$ is Richardson constant, $k$ is the Boltzmann constant, $\Phi_{\beta}$ is the barrier height in $\mathrm{eV}$. To determine the barrier height of the photoelectrode, a graph of $\log \left(I_{0} / T^{2}\right)$ with $1000 / T$ was plotted. The plot of $\log \left(I_{0} / T^{2}\right)$ with $1000 / T$ for the representative sample is shown in Figure 8. From the slope of the linear region of plots, the barrier height was determined. The barrier height value is found to be $0.583 \mathrm{eV}$.

\subsection{Power Output Characteristics}

Solar cell may operate over a wide range of voltages and currents. The photovoltaic 


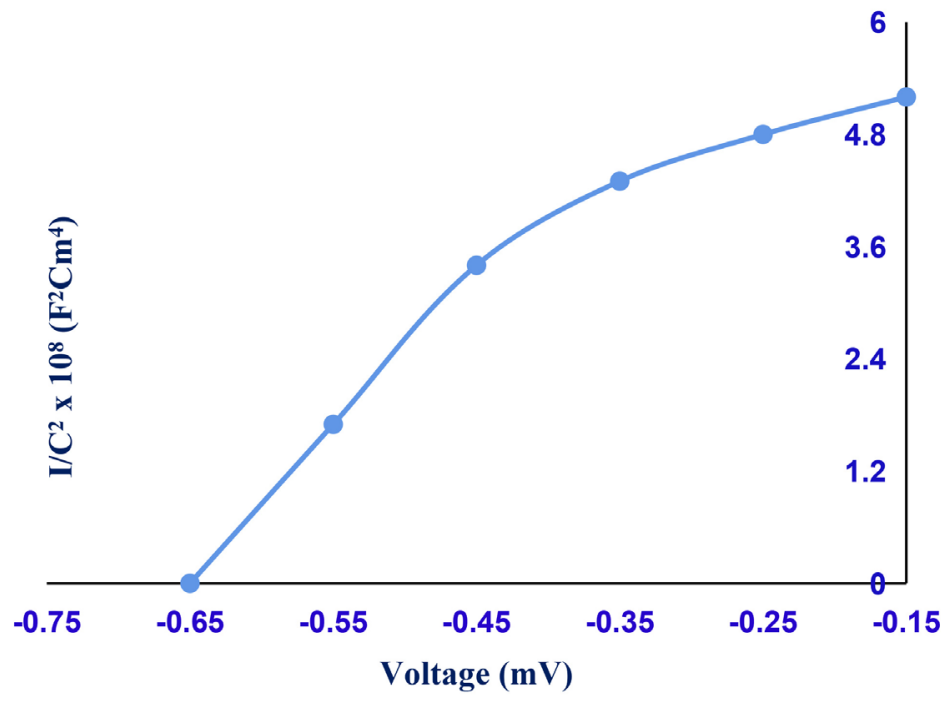

Figure 7. C-V characteristics of ZnTe photovoltaic solar cell.

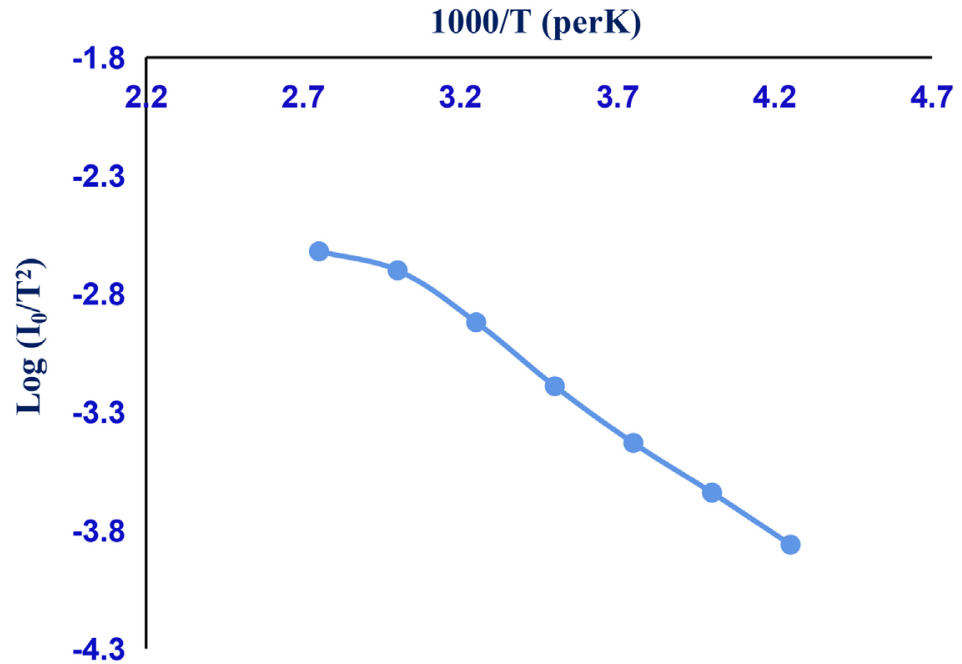

Figure 8. Determination of barrier height of $\mathrm{ZnTe}$ photovoltaic solar cell.

solar cell is illuminated with the light constant intensity of the current voltage characteristics shift in the four quadrants, this behavior is in accordance with the theory of solar cells acting as an electricity generator. By applying the resistive load on an irradiated cell continuously from a short circuit to a very high value of open circuit it is possible to determine the maximum power point $\left(P_{m}=V_{m} \times\right.$ $\left.I_{m}\right)$, that is the load for which the cell can deliver maximum electrical power. The Energy conversion efficiency ( $\eta$ "eta") of a cell is the percentage of power converted of the observed light to electrical energy, and collected and are shown by the following equation.

$$
\left[\eta=\frac{P_{m}}{E \times A_{c}}\right] .
$$

where $E$ is power of input light $\left(\mathrm{mW} / \mathrm{cm}^{2}\right)$ and $A_{c}$ is the surface area of the cell in 
$\mathrm{cm}^{2}$. Another measuring term in the overall behavior of a cell is the fill factor $(f f)$, which is the ratio of the maximum power $\left(V_{m} \times I_{m}\right)$ divided by the short circuit current $\left(I_{s c}\right)$ and open circuit voltage $\left(V_{o c}\right)$ in light current voltage $(I-V)$ characteristics of the cells can be measured by the following equation.

$$
f f=\left[\frac{P_{m}}{V_{o c} \times I_{s c}}\right]=\left[\frac{\eta \times E \times A_{c}}{V_{o c} \times I_{s c}}\right] .
$$

The open circuit voltage and short circuit current are found to be $150 \mathrm{mV}$ and $25.6 \mu \mathrm{A}$, respectively. The power efficiency conversion factor can be studied by the following equation.

$$
\eta_{\max }=\left[V_{\text {redox }}-V_{f b}\right] \times\left[\frac{e}{E_{g}}\right] .
$$

where $V_{f b}$ is the flat band potential, $V_{\text {redox }}$ the electrolyte redox potential and $E_{g}$ is the energy band gap. It is important to note here that $V_{o c}$ and $\eta$ depend on $V_{f b}$ and $E_{g}$. The photovoltaic power output characteristics for a cell under illumination of $30 \mathrm{~mW} / \mathrm{cm}^{2}$ shows Figure 9. The calculation shows the fill factor is $24.86 \%$. The power conversion efficiency is found to be $0.49 \%$. The low efficiency may be due to high series resistance and interface states which are responsible for recombination mechanism [5] [20] [21]. The value of series resistance and shunt resistance were found to be $263(\Omega)$ and $689(\Omega)$, respectively.

\subsection{Study of Photo and Spectral Response}

The logarithmic variation of open circuit voltage with incident light intensity was observed from photo response measurements whereas short circuit current follows almost a straight-line path. Figure 10 shows variation of short circuit current and open circuit voltage which were measured as function of light intensity whereas, variation of open circuit voltage as a function of light intensity was shown in Figure 11. The photoelectrode-electrolyte interface modeled as a Schottky

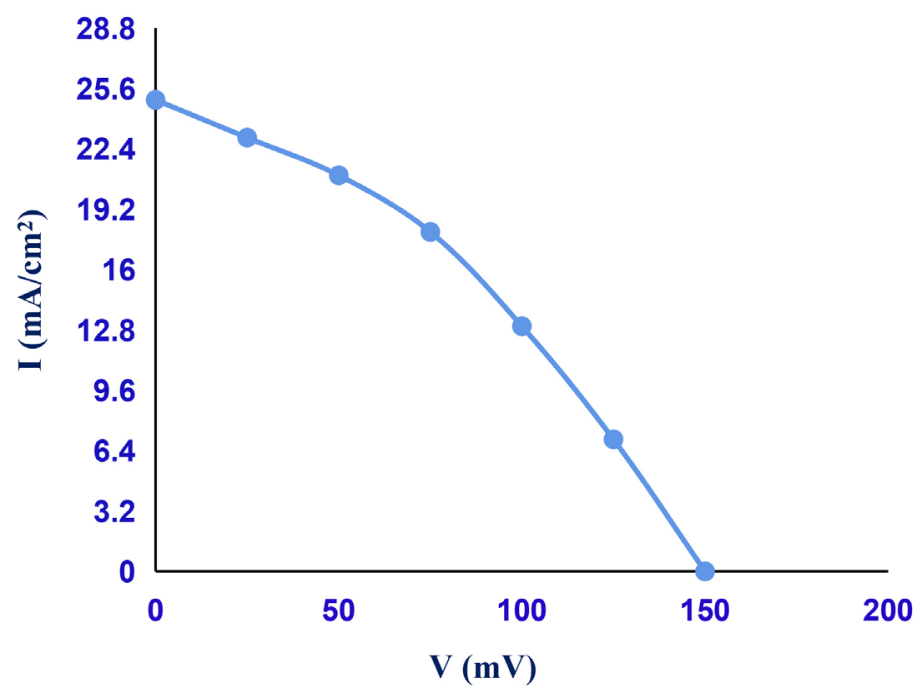

Figure 9. Power output curve for ZnTe photovoltaic solar cell. 


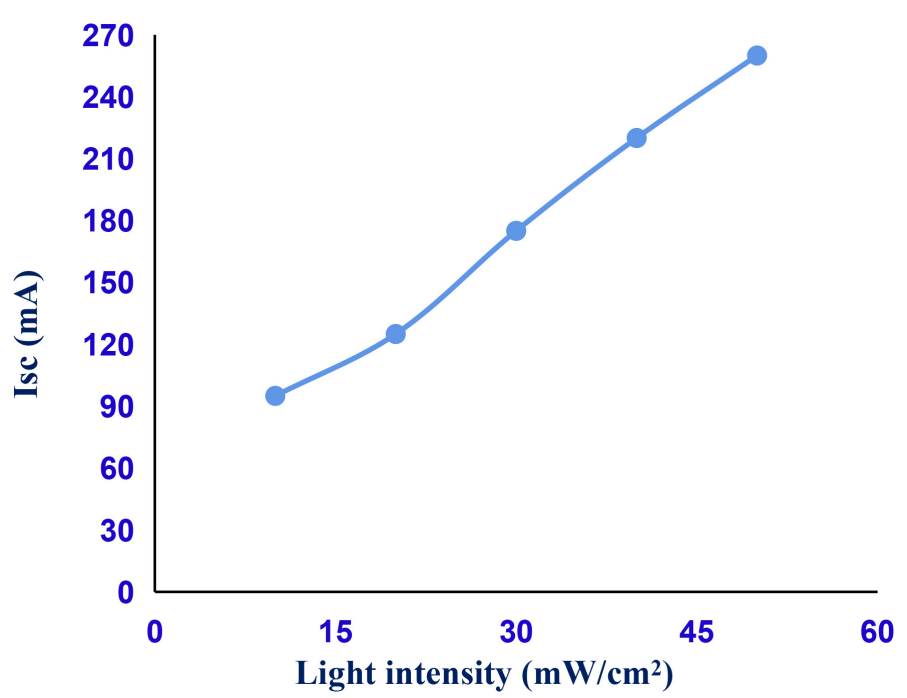

Figure 10. Photo response as a function of Isc for $\mathrm{ZnTe}$ photoelectrode.

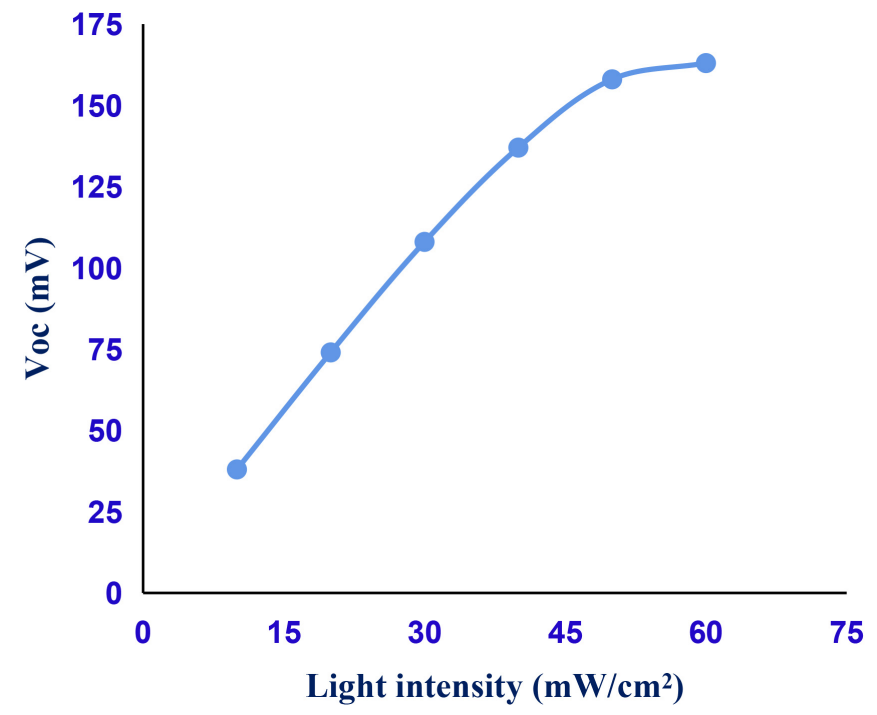

Figure 11. Photo response as a function of Voc for $\mathrm{ZnTe}$ photoelectrode.

barrier solar cell it is possible to represent the current-voltage relationship [19] [20].

$$
I=I_{p h}-I_{d}=I_{p h}-\left[I_{0} \exp \left(\frac{q_{v}}{n_{d} k T}\right)\right]-1 .
$$

where, $I_{p h}$ the photocurrent densities, $I$ is the net current density, $I_{0}$ the reverse saturation current density, $I_{d}$ the dark current density, $V$ the applied bias voltage and $n_{d}$ is the junction ideality factor. In bias voltage condition $V>3 \mathrm{kT} / q$ and at equilibrium open circuit conditions

$$
\begin{gathered}
I_{p h}=I_{d} \text { and } V=V_{o c} \text { thus, } \\
V_{o c}=\left[\frac{n_{L} k T}{q}\right] \times I_{n}\left[\frac{I_{s c}}{I_{0}}\right] .
\end{gathered}
$$


where, $V_{o c}$ is the open circuit voltage and $I_{s c}$ is the short circuit current. As $I_{s c} \gg$ $I_{0}$, a plot of $\log I_{s c}$ against $V_{o c}$ should give a straight line and from the slope of the line the lighted ideality factor can be determined. Figure 12 shows the plot of log $I_{s c}$ with $V_{o c}$ for $\mathrm{ZnTe}$ photoelectrode. The lighted ideality factor was calculated and found to be 2.87 .

Spectral response is studied by the current verse's wavelength the shorter wavelength is high current absorption and higher the current value and higher wavelength are low current absorption and lower the current value. Photovoltaic cell is one of the most powerful techniques to measure the performance of the spectral response cell qualitatively. Therefore, the spectral response of a cell has been recorded in the $400-1050 \mathrm{~nm}$ wavelength range. The photocurrent action spectra were examined and are shown in Figure 13. It is seen that spectra attain

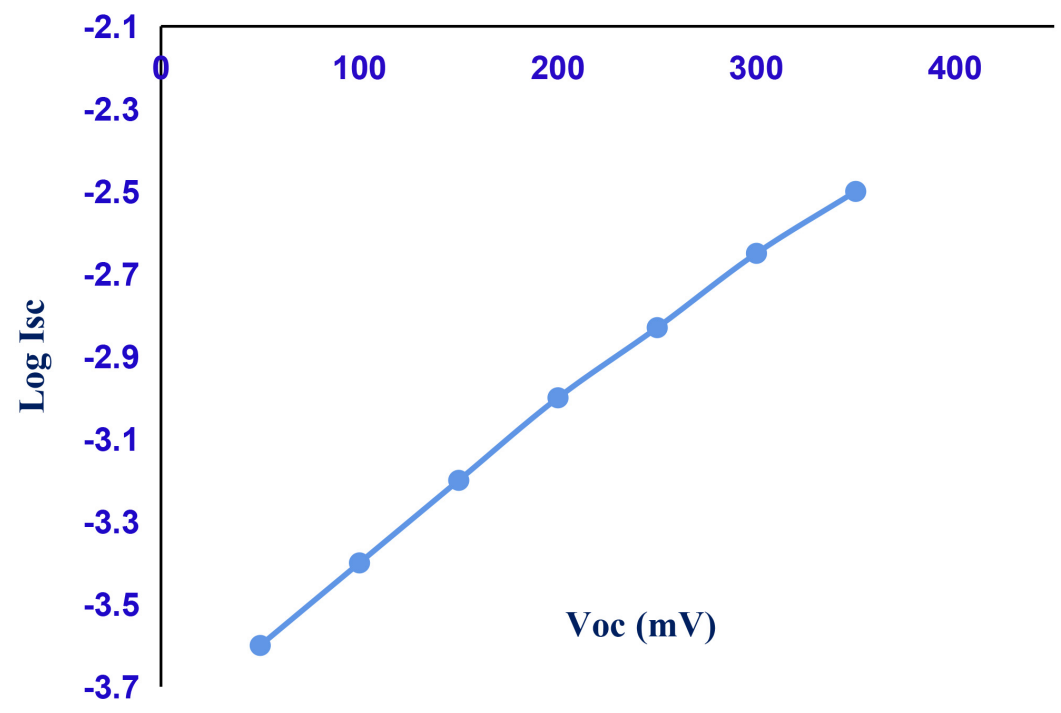

Figure 12. Determination of lighted ideality factor for ZnTe photoelectrode.

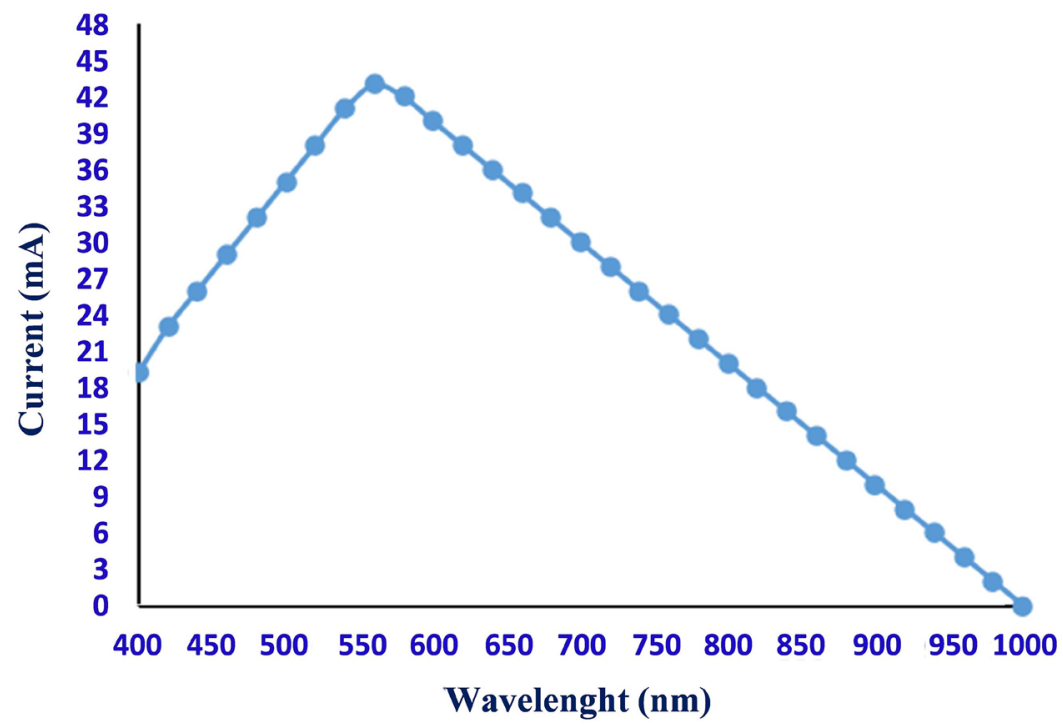

Figure 13. Determination of spectral response for $\mathrm{ZnTe}$ photoelectrode. 
maximum value of current at $\lambda=560 \mathrm{~nm}$ and decreases with increase in wavelength. The decrease in current on longer wavelength side may be attributed to non-optimized thickness and transition between defect levels. The maximum current is obtained corresponding to $\lambda=560 \mathrm{~nm}$.

\section{Conclusion}

The photovoltaic solar cell of zinc telluride thin films can be successfully deposited by using zinc sulphate tartaric acid, and liquor ammonia and sodium telenosulphate onto a stainless steel plate. The photovoltaic solar cell can be easily fabricated using ZnTe photoanode, sulphide-polysulphide as the electrolyte, CoS-treated graphite rod as a counter electrode. A saturated calomel electrode was used as a reference electrode. Through photovoltaic solar cell has some disadvantage associated it, but the disadvantages are expected to overcome as the technology advances, since the technology is advancing, the cost of solar plates, as well as the installation cost, will decrease down so that everybody can effort to install the system. Furthermore, the government is laying much emphasis on solar energy so after some years we may expect that every household and also every electrical system is powered by solar or renewable energy.

\section{Acknowledgements}

One of the author (KCR) thankfully acknowledge to Dr. V. M. Patil, the Principal, The New college, Kolhapur for providing all facilities to do this work.

\section{Conflicts of Interest}

The author declares no conflicts of interest regarding the publication of this paper.

\section{References}

[1] Potlog, T., Khrypunov, G., Kaelin, M., Zogg, H. and Tiwari, A.N. (2007) Thin-Film Compound Semiconductor. In: Gessert, T., Durose, K., Heske, C., Marsillac, S. and. Wada, V., Eds., Photovoltaics-2007, Vol. 1012, Cambridge University Press, Cambridge, 181-188. https://www.cambridge.org/

[2] Wu, X. (2004) High-Efficiency Polycrystalline CdTe Thin-Film Solar Cells. Solar Energy, 77, 803-814. https://doi.org/10.1016/j.solener.2004.06.006

[3] Gutowski, J., Presser, N. and Kudlek, G. (1990) Optical Properties of ZnSe Epilayers and Films. Physica Status Solidi $(A), 120,11-59$. https://doi.org/10.1002/pssa.2211200102

[4] Li, H. and Jie, W. (2003) Growth and Characterizations of Bulk ZnSe Single Crystal by Chemical Vapor Transport. Journal of Crystal Growth, 257, 110-115. https://doi.org/10.1016/S0022-0248(03)01431-3

[5] Swanepoel, R. (1983) Determination of the Thickness and Optical Constants of Amorphous Silicon. Journal of Physics E: Scientific Instruments, 16, 1214-1219. https://doi.org/10.1088/0022-3735/16/12/023

[6] Meillaud, F., Shah, A., Droz, C., Vallat-Sauvain, E. and Miazza, C. (2006) Efficiency Limits for Single-Junction and Tandem Solar Cells. Solar Energy Materials and So- 
lar Cells, 90, 2952-2959. https://doi.org/10.1016/j.solmat.2006.06.002

[7] Orita, M., Narushima, T. and Yanagita, H. (2007) Transparent Conductive Cu-doped ZnSe Film Deposited at Room Temperature Using Compound Sources Followed by Laser Annealing. Japanese Journal of Applied Physics, 46, 976-978. https://doi.org/10.1143/JJAP.46.L976

[8] Lalitha, S., Sathya Moorthy, R., Senthilarasu, S., Subbarayan, A. and Natarajan, K. (2004) Characterization of CdTe Thin Film-Dependence of Structural and Optical Properties on Temperature and Thickness. Solar Energy Materials and Solar Cells, 82, 187-199. https://doi.org/10.1016/j.solmat.2004.01.017

[9] Demtsu, S. and Sites, J. (2006) Effect of Back-Contact Barrier on Thin-Film CdTe Solar Cells. Thin Solid Films, 510, 320-324. https://doi.org/10.1016/j.tsf.2006.01.004

[10] Corwine, C., Pudov, A.O., Gloeckler, M., Demtsu, S.H. and Sites, J.R. (2004) Copper Inclusion and Migration from the Back Contact in CdTe Solar Cells. Solar Energy Materials and Solar Cells, 82, 481-489. https://doi.org/10.1016/j.solmat.2004.02.005

[11] Gessert, T.A., Mason, A.R., Reedy, R.C., Matson, R., Coutts, T.J. and Sheldon, P. (1995) Development of Rf Sputtered, Cu-Doped ZnTe for Use as a Contact Interface Layer to p-CdTe. Journal of Electronic Materials, 24, 1443-1449. https://doi.org/10.1007/BF02655462

[12] Zhou, J., Wu, X., Duda, A., Teeter, G. and Demtsu, S.H. (2007) The Formation of Different Phases of $\mathrm{Cu}_{\mathrm{x}} \mathrm{Te}$ and Their Effects on CdTe/CdS Solar Cells. Thin Solid Films, 515, 7364-7369. https://doi.org/10.1016/j.tsf.2007.03.032

[13] Li, J.V., Duenow, J.N., Kuciauskas, D., Kanevce, A., Dhere, R.G., Young, M.R. and Levi, D.H. (2013) Electrical Characterization of Cu Composition Effects in CdS/CdTe Thin-Film Solar Cells with a ZnTe: Cu Back Contact. IEEE Journal of Photovoltaics, 3, 1095-1099. https://doi.org/10.1109/JPHOTOV.2013.2257919

[14] Chu, T.L., Chu, S.S., Ferekides, C., Wu, C.Q., Britt, J. and Wang, C. (1991) $13.4 \%$ Efficient Thin Film CdS/CdTe Solar Cells. Journal of Applied Physics, 70, 7608-7612. https://doi.org/10.1063/1.349717

[15] Li, J., Diercks, D.R., Ohno, T.R., Warren, C.W., Lonergan, M.C., Beach, J.D. and Wolden, C.A. (2015) Controlled Activation of ZnTe: Cu Contacted CdTe Solar Cells Using Rapid Thermal Processing. Solar Energy Materials and Solar Cells, 133, 208-215. https://doi.org/10.1016/j.solmat.2014.10.045

[16] Dobson, K.D., Visoly-Fisher, I., Hodes, G. and Cahen, D. (2000) Stability of CdTe/ CdS Thin Film Solar Cells. Solar Energy Materials and Solar Cells, 62, 295-325. https://doi.org/10.1016/S0927-0248(00)00014-3

[17] Hankare, P.P., Bhuse, V.M., Garadkar, K.M., Delekar, S.D. and Mulla, I.S. (2003) CdHgSe Thin Films: Preparation, Characterization and Optoelectronic Studies. Semiconductor Science and Technology, 19, 277. https://doi.org/10.1088/0268-1242/19/2/027

[18] Bayhan, H. and Kavasoğlu, A.S. (2005) Tunnelling Enhanced Recombination in Polycrystalline CdS/CdTe and CdS/Cu(In,Ga)Se2 Heterojunction Solar Cells. Solid-State Electronics, 49, 991-996. https://doi.org/10.1016/j.sse.2005.03.012

[19] Ou, S.S., Stafsudd, O.M. and Basol, B.M. (1984) Current Transport Mechanisms of Electrochemically Deposited CdS/CdTe Heterojunction. Solid-State Electronics, 27, 21-25. https://doi.org/10.1016/0038-1101(84)90088-1

[20] Kranz, L., Gretener, C., Perrenoud, J., Schmitt, R., Pianezzi, F., La Mattina, F., Blösch, P., Cheah, E., Chirila, A., Fella, C.M., et al. (2013) Doping of Polycrystalline CdTe for High-Efficiency Solar Cells on Flexible Metal Foil. Nature Communications, 4, 
Article No. 2306. https://doi.org/10.1038/ncomms3306

[21] Salavei, A., Menossi, D., Piccinelli, F., Kumar, A., Mariotto, G., Barbato, M., Meneghini, M., Meneghesso, G., Di Mare, S., Artegiani, E., et al. (2016) Comparison of High Efficiency Flexible CdTe Solar Cells on Different Substrates at Low Temperature Deposition. Solar Energy, 139, 13-18. https://doi.org/10.1016/j.solener.2016.09.004

[22] Hadrich, M., Heisler, C., Reis, U., Kraft, C. and Metzner, H. (2011) Back Contact Formation of the Thin Cadmium Telluride Solar Cells. Thin Solid Films, 519, 71567159. https://doi.org/10.1016/j.tsf.2010.12.144 